\title{
Two Cases of Transoral Resection of Retropharyngeal Lymph Node Metastasis from Papillary Thyroid Carcinoma Diagnosed by PET-CT Follow-Up after Lateral Neck Dissection
}

\author{
Seung-Hwan Bang, Tae-Hun Kim, Jae Gu Cho ${ }^{(D)}$, and Jeong Soo Woo \\ Department of Otorhinolaryngology-Head and Neck Surgery, Guro Hospital, Korea University College of Medicine, Seoul, Korea
}

\author{
측경부 절제술 후 $\mathrm{PET}-\mathrm{CT}$ 추적 검사로 진단된 갑상선 유두암종의 \\ 후인두 림프절전이에 대한 경구강 절제술 2예 \\ 방승환 · 김태훈 · 조재구 · 우정수 \\ 고려대학교 의과대학 구로병원 이비인후-두경부외과
}

\author{
Received August 1, 2018 \\ Revised October 10, 2018 \\ Accepted November 19, 2018 \\ Address for correspondence \\ Jeong Soo Woo, MD, PhD \\ Department of Otorhinolaryngology- \\ Head and Neck Surgery, \\ Guro Hospital, Korea University \\ College of Medicine, \\ 148 Gurodong-ro, Guro-gu, \\ Seoul 08308, Korea \\ Tel $+82-2-2626-3187$ \\ Fax $+82-2-868-0475$ \\ E-maildiakonos@korea.ac.kr
}

The presence of lymph node metastasis of thyroid papillary carcinoma usually occurs in the internal jugular and paratracheal space on the side of the lesion. For this reason, metastasis to the retropharyngeal lymph nodes from papillary thyroid carcinoma is rare. We currently experienced two cases of retropharyngeal lymph node metastasis of thyroid papillary carcinoma. Both patients had a history of total thyroidectomy and ipsilateral neck dissection and had undergone retropharyngeal lymph node dissection via transoral approach after the diagnosis of retropharyngeal node metastasis. We suggest that the metastatic retropharyngeal lymph nodes can be successfully removed through transoral apparoach. The diagnosis of this rare lymph node metastasis requires sufficient imaging studies such as MRI, CT or PET-CT as well as appropriate history taking and physical examination.

Korean J Otorhinolaryngol-Head Neck Surg 2019;62(8):475-80

Key Words Papillary carcinoma · Lymphatic metastasis · Thyroid neoplasms.

\section{서 론}

갑상선 유두암종의 경부 림프절 전이는 흔한 편이며, 30 $80 \%$ 에 달하는 것으로 알려져 있다. 그러나 이중 대다수가 내 경정맥군(internal jugular chain)을 따라 발생하고, 후인두나 부인두 림프절의 전이는 주로 경부 절제술 후에 림프절 흐름 의 변화가 생기면서 발생하는 것으로 알려져 있으며, 국내에 서 보고된 바가 매우 드문 경우이다.

후인두 림프절에 전이된 갑상선 유두암종은 인두 내에 돌출
된 종괴 형태로 나타나지 않는다면 문진이나 신체 검진에서 의심하기 힘들고, $\mathrm{TG}-\mathrm{Ag}$ level과 같은 갑상선 기능검사를 포함하여 CT나 MRI, 혹은 PET-CT와 같은 영상학적 진단 역 시 필요하다.

이에 저자들은 경부 절제술의 병력을 가진 환자의 PET-CT 추적 검사를 통해 갑상선 유두암종의 후인두 림프절 전이를 의심하고, 경구강 접근법을 통해 절제술을 시행한 증례들에 대해 보고하고자 한다. 


\section{증 례}

증 례 1

40세 여성이 PET-CT에서 발견된 이상 소견을 주소로 본원 이비인후과 외래 내원하였다. 환자는 2년 전 양측 갑상선 유두 암종(pT3N1bM0, 수집된 17개의 림프절 중 8개의 전이 확인됨)
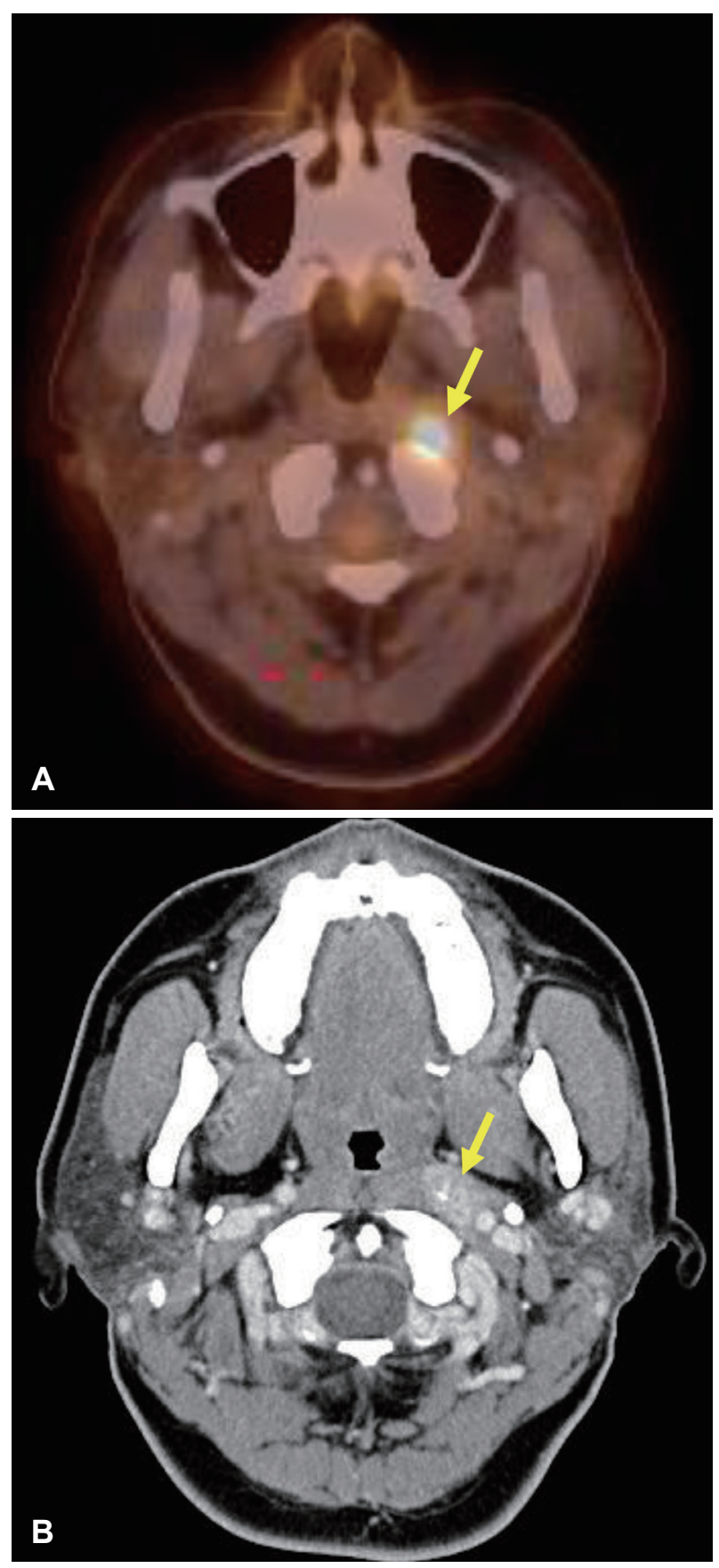

Fig. 1. PET-CT axial view showing hypermetabolic lesion at left retropharyx (arrow) (A). Neck CT axial view showing heterogeneous enhanced retropharyngeal lesion which is located close with external carotid artery (arrow) (B).
으로 갑상선 전절제술, 중앙 및 좌측 경부 절제술(level II, III, $\mathrm{IV}, \mathrm{V})$ 을 시행 받고 방사성 요오드 치료 후 외래 추적 관찰 중이었고, $\mathrm{TG}-\mathrm{Ag}$ 의 상승으로 시행한 $\mathrm{PET}-\mathrm{CT}$ 에서 좌측 후 인두의 림프절 전이가 의심되는 병변이 발견되었다(Fig. 1A).

환자가 호소하는 증상이 없고, 내원 당시 양측 경부로 촉지 되거나 인·후두 내시경에서 관찰되는 병변은 없었으나, PET$\mathrm{CT}$ 에서 보이는 경추 1 번(C1) 높이의 좌측 후인두 병변은 경부

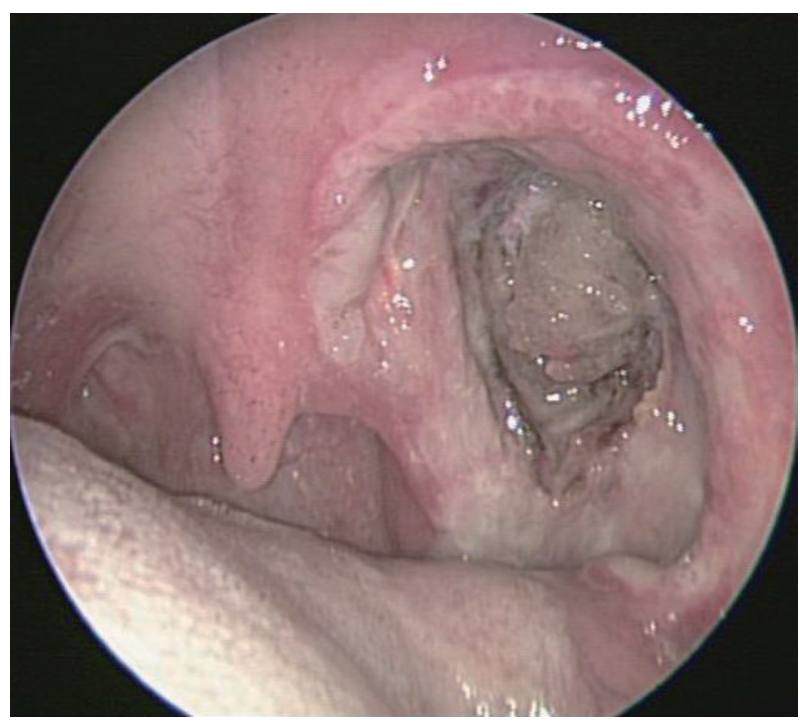

Fig. 2. Endoscopic findings of the patient's oral cavity taken 1 day after the operation. The wound are healing with TachoSi ${ }^{\circledR}$ (fibrinogen \& thrombin material, Takeda Pharm Co., Ltd.).

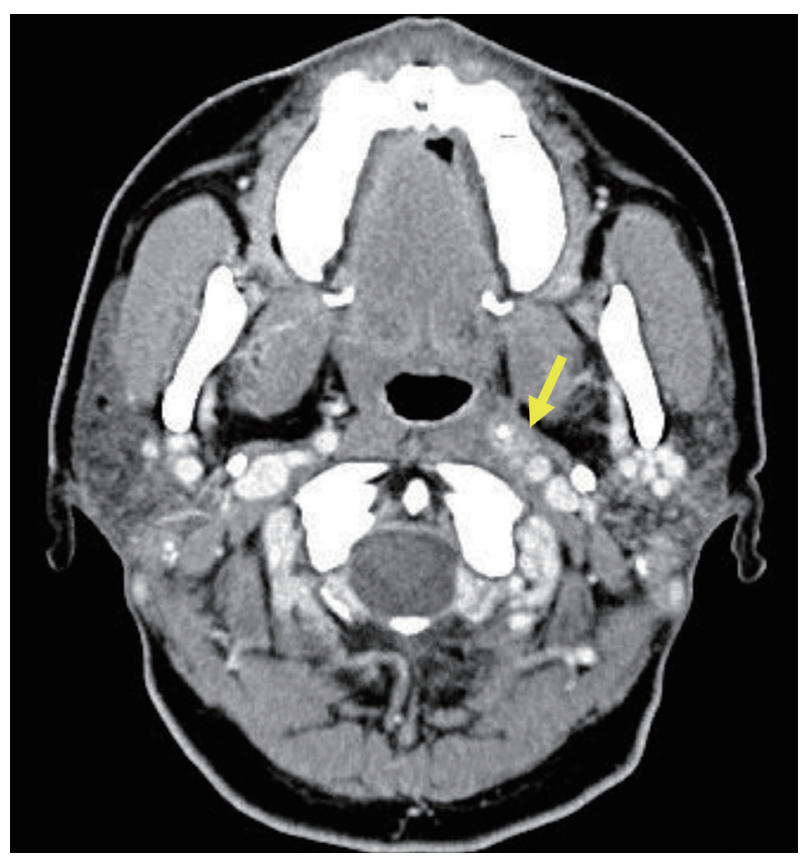

Fig. 3. CT image that was performed after 16 months after the operation. A III-defined focal enhancement in left retropharynx which was considered as remnant tumor or post operative change was observed (arrow). 
$\mathrm{CT}$ 에서도 $1.9 \times 1.1 \mathrm{~cm}$ 크기의 비균일하고 내부에 석회화를 포함하는 림프절 전이암이 의심되는 모습으로 관찰되었다 (Fig. 1B).

수술은 경구강 접근법을 통해 측인두 절제술과 함께 이루 어졌다. 좌측 상인두 수축근(superior constrictor muscle)을 포함한 구인두벽을 박리하여 내부의 지방층을 노출한 후, 경 부 CT에서 관찰되는 위치의 후인두 림프절을 촉지하여 주
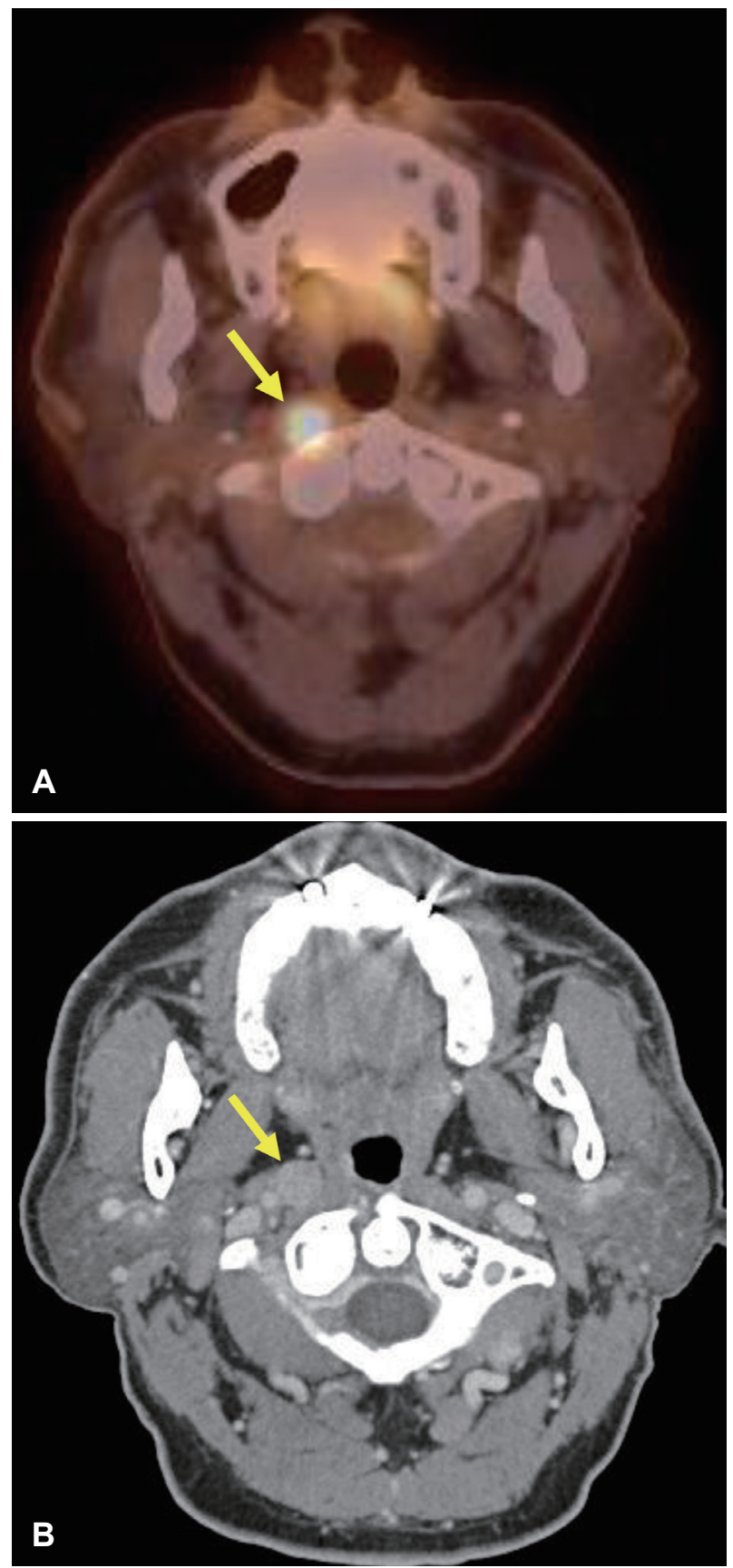

Fig. 4. PET-CT axial view showing hypermetabolic lesion at right retropharyx (arrow) (A). CT axial view showing heterogeneous enhanced retropharyngeal lymph node enlargement (arrow) (B).
변 연결조직(lymph areolar tissue)을 포함하여 경동맥집 (carotid sheath)과 날개근(pterygoid muscle)이 노출될 때까 지 절제를 시행(Fig. 2)하였고, 동결 절편 검사 및 최종 조직 병리보고에서 전이성 갑상선 유두암종이 확인되었다. 수술 후 시행한 경부 $\mathrm{CT}$ 추적 검사에서 잔여 병변이 의심되는 소 견 있었으나, 최종 조직병리보고에서 절제된 검체 내에 국한 된 병변임을 확인하였고, 수술 후 현저한 $\mathrm{TG}-\mathrm{Ag}$ 감소를 보인 후(수술 2개월 전: $9.0 \mathrm{ng} / \mathrm{mL}$, 수술 2개월 후: $1.8 \mathrm{ng} / \mathrm{mL}$ ) 수치 유지되고 있으며, 1년 4개월간 반복적인 경부 CT에서 해 당 부위의 변화 없어 수술 후 발생한 생리적 변화(post-operative change)로 판독 받아 방사성 요오드 치료 없이 추적 관 찰 중 합병증 및 재발한 소견 없는 상태이다(Fig. 3).

\section{증 례 2}

74세 남성이 PET-CT에서 발견된 이상 소견을 주소로 본 원 이비인후과 외래 내원하였다. 환자는 4년 전 우측 갑상선 유두암종으로 갑상선 전절제술, 1 년 전 우측 경부 림프절 전 이(rTON1bM0, 수집된 32개의 림프절 중 3개의 전이 확인됨) 로 우측 경부 절제술(level II, III, IV, Vb)을 시행 받고 방사성 요오드 치료 후 외래 추적 관찰 중이었고, $\mathrm{TG}-\mathrm{Ag}$ 상승 소견 있어 시행한 $\mathrm{PET}-\mathrm{CT}$ 추적 검사에서 후인두의 림프절 전이 가 의심되는 병변이 발견되었다(Fig. 4A).

증례 1 과 유사하게, 환자가 호소하는 증상이 없고, 내원 당 시 양측 경부로 촉지되거나 인후두 내시경에서 관찰되는 병 변은 없었으나, PET-CT에서 보이는 경추 1 2번(C1 2) 높이 의 우측 후인두 병변은 경부 전산화단층촬영에서도 $1.1 \times 1.1$ $\mathrm{cm}$ 크기의 비균일한 조영 증강을 보이며 림프절 전이암이 의심되는 모습으로 관찰되었다(Fig. $4 \mathrm{~B}$ ).

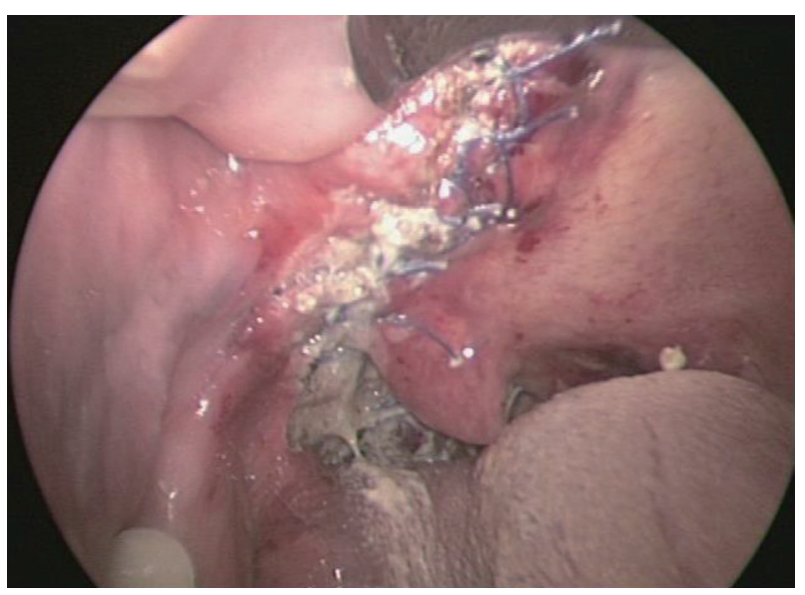

Fig. 5. Endoscopic findings of the patient's oral cavity taken 1 day after the operation. After tonsillectomy, additional incision on soft palate vertically was done for exposure of retropharyngeal lymph node. 


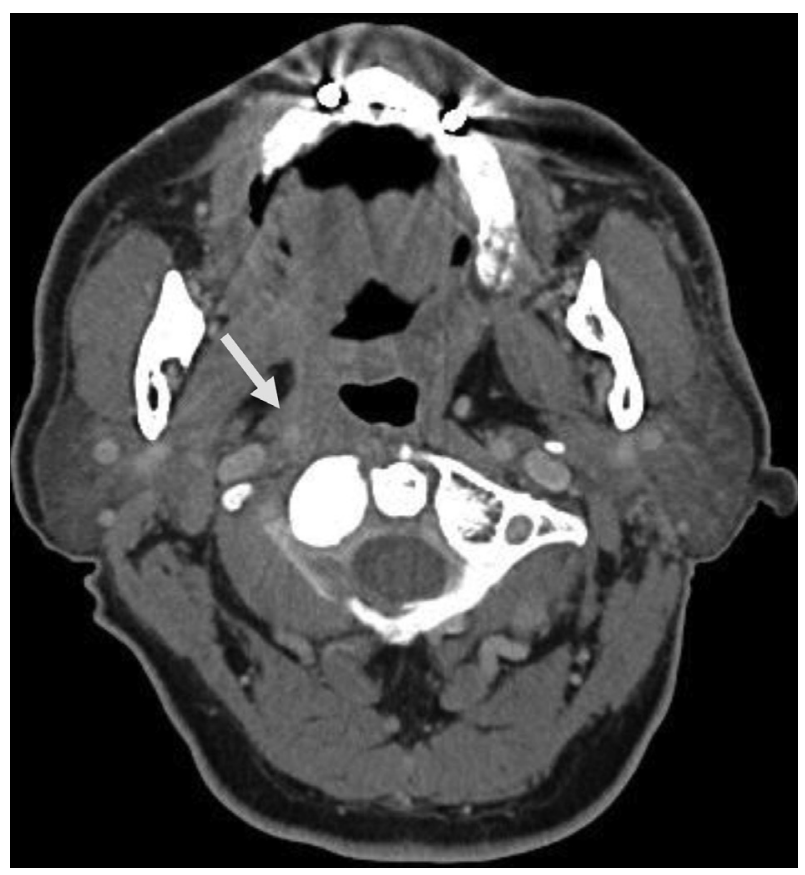

Fig. 6. CT image that was performed after 3 months after the operation. There was no sign of remnant or recurrence on previous operation site (arrow).

수술은 증례 1과 마찬가지로 경구강 접근법을 통해 이루어 졌고, 우측 편도 절제술 후 지방층이 노출될 때까지 심층을 박리한 후 CT에서 관찰되는 후인두 림프절에 대해 절제술을 시행(Fig. 5)하였고, 최종 조직병리보고상 2개의 림프절에서 전이성 갑상선 유두암종이 확인되었다. 수술 후 최종 조직병 리보고와 추적 관찰 경부 $\mathrm{CT}$ 에서 잔여 병변 없는 것을 확인 하였고, TG-Ag 역시 감소한 후(수술 2개월 전: $11.4 \mathrm{ng} / \mathrm{mL}$, 수술 2개월 후: $0.7 \mathrm{ng} / \mathrm{mL}$ ) 유지되는 상태로, 방사성 요오드 치료 등의 추가 치료 없이 1년 2개월간 정기적인 경부 CT 포 함 경과 관찰 중 합병증 및 재발 소견 없는 상태이다(Fig. 6).

\section{고 찰}

후인두의 림프절은 nodes of Rouviere로도 불리며 C1 level 에서 잘 관찰된다. 이는 internal carotid artery의 medial side 에서 주로 관찰된다. ${ }^{1,2)}$ 갑상선 유두암종의 후인두 림프절 전 이는 매우 드문데, Desuter 등희 읜구에 따르면 갑상선 유 두암종의 약 $0.43 \%$ 만이 부인두 림프절 전이를 보인다고 한 다. 또한 Togashi 등의 연구에서는 19년간 갑상선 유두암종 수술을 받은 1449 명의 환자 중 12 명만 후인두 림프절 전이를 보였다고 보고하였다. 국내에서도 1 건의 갑상선 유두암종의 부인두 림프절 전이 사례와 후인두 림프절 전이 사례에 관한 2개의 연구가 이루어진 바 있다. ${ }^{5-7)}$ 그러나 이는 갑상선 유두암 종의 높은 진단율을 보이는 국내 현황에 대비하여 매우 적다
고 할 수 있을 것이다.

갑상선의 림프 흐름은 복잡하며 네 가지 경로로 구분된다 고 한다. 경부 절제술이나 경부 림프절의 악성 종양 전이는 이 러한 림프 흐름을 역행하게끔 만들 수 있는데 이를 통해 후 인두 림프절 전이를 일으킬 수 있다고 한다. ${ }^{1)}$ 본 증례에서도 2개의 증례 모두 갑상선암 진단 당시에는 후인두 림프절 전이 를 보이지 않았으며 측경부 절제술을 받은 과거력이 있었다.

한편, 갑상선 유두암종의 부인두 혹은 후인두 림프절 전이 에 대해서 수술이 유일한 효과적 치료라고 보고된 바 있다. ${ }^{3)}$ 후인두 림프절 절제를 위한 몇 가지 접근 방법이 있는데, 가 장 전통적인 접근법은 경부 접근법이다. 술식에 따라 경하악 골 접근, 경이하선 접근 등의 방법으로 나뉘게 되는데, 보통 피부의 절개선으로부터 $4 \sim 5 \mathrm{~cm}$ 가량의 깊이에 병변이 위치 하게 되어 박리 범위가 넓고 깊어 접근법 중에서 주변 신경과 혈관계의 손상이 가장 많은 침습적인 방법이다. 하지만 접근 법 중 가장 병변의 노출이 수월하고 수술을 위한 공간이 넓 은 장점을 가지고 있어 가장 많이 사용됐던 접근법이기도 하 다. 국내에서 보고된 $\mathrm{Chu}$ 등ㄱㅇㅢ 증례에 포함된 갑상선 유두 암종으로 진단받은 5명과 Park 등의 증례에 포함된 2명, 그 리고 최근의 Togashi 등의 연구에 포함되었던 12 명의 갑상 선 유두암종의 후인두 림프절 전이 환자들은 모두 경부 접근 법을 이용한 수술을 받았다.

단일 후인두 림프절 전이의 경우 경구강 접근법을 통해 제 거할 수 있다고 보고되었다. ${ }^{2}$ 경구강 접근법은 경부 접근법의 침습적이고 이환율이 높다는 단점을 보완하기 위해 시행되 기 시작한 방법이다. 상대적으로 적은 박리를 통해 병변에 직 접 접근하는 것이 가능하여 덜 침습적이고 주변 신경과 혈관 계의 손상이 적어 재원 및 회복 기간이 단축된다는 장점이 있어 주로 크기가 작은 단일 후인두 림프절의 절제를 목적으 로 사용하게 되지만, 경부 접근법에 비해 병변 노출이 제한적 이고, 주변 구조로 침범이 있는 경우에 박리나 접근, 병변의 절제가 매우 어려운 문제점이 있다.

내시경을 이용한 접근은 경부 접근법과 경구강 접근법 모두 에서 보조적으로 사용될 수 있으며, 육안으로 관찰이 어려운 심층부나 각진 부위의 병변 노출과 조작에 도움을 줄 수 있 는 반면, 상대적으로 어둡고 좁은 시야와 공간을 사용해야 하 고 조작을 위한 수술 도구까지 운용해야 한다면 공간적 제한 이 매우 심할 수 있다.

로봇을 이용한 접근을 이용하면 좁은 공간 안에서 조작이 가능하고, 경구강 접근법보다도 덜 침습적이라는 장점이 있 으나 고비용, 장시간의 수술이라는 단점이 있다. 국내에서는 갑상선 유두암종이 아닌, 구인두나 하인두암의 후인두 림프절 전이를 로봇을 이용한 경구강 접근법으로 수술한 예가 
Byeon 등 ${ }^{8)}$ 의 증례에 포함된 바 있다.

증례 1 과 2의 환자들은 모두 단일 후인두 림프절 전이 소 견이 확인되어 경구강 접근법을 이용하여 림프절 절제술을 시행 받았다. 증례 1 의 경우 후인두 림프절 절제술 시행 후 5 개월 뒤 시행한 경부 CT상 후인두 림프절에 잔여 병변이 의심 된다는 판독이 있었으나 TG-Ag level의 상승이 없고 1년 4개 월간 6차례의 경부 CT 추적 검사에서 크기나 모양 변화 없 어 수술 후 발생한 생리적 변화로 판단되어 외래 추적 관찰 중이다. 증례 2 역시 구강 내 접근법으로 효과적으로 후인두 림프절을 제거하였으며 재발 소견 없이 추적 관찰 중인 사례 이다. 위 2 개의 증례를 볼 때 단일 후인두 림프절은 경구강 접근법으로 효과적으로 제거할 수 있으며, 병변의 위치에 따 라 본 증례들처럼 로봇이나 내시경 등의 장비 없이 보다 간 단한 수술이 가능하다는 점을 알 수 있다. 다만 경구강 접근 법을 이용한 절제를 시행한 후 TG-Ag level이 다시 상승하거 나 영상학적 검사에서 잔여 혹은 재발 병변의 소견이 있다면, 수술 부위의 유착과 변형, 그리고 재수술 후 발생할 수 있는 구강 내 점막의 회복 지연 등의 위험성을 고려하여 경부 접근 법을 이용하는 것을 고려해야 할 것이다.

갑상선 질환과 경부 림프절은 대개 초음파로 검사하지만 upper jugular chain의 림프절은 조영 증강 경부 CT를 촬영할 것을 권고하고 있다. ${ }^{1)}$ 마찬가지로 후인두 림프절에 대한 평가 를 위해서 초음파보다는 CT나 MRI가 더 적합하다.,5) PET$\mathrm{CT}$ 는 후인두 림프절 전이에 대한 평가를 위해 다양한 연구

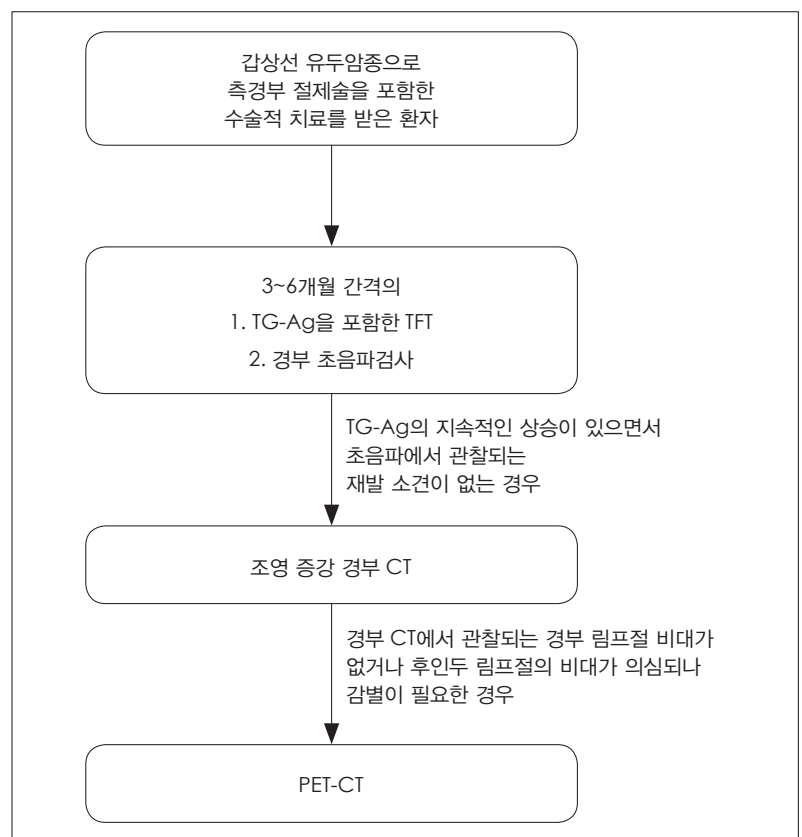

Fig. 7. Algorithm for the diagnosis of retropharyngeal lymph node metastasis in patients underwent lateral neck dissection of the papillary thyroid carcinoma. TFT: thyroid function test.
들에서 사용되었고, 국내에서도 방사성 요오드 스캔에서 음 성이 나온 갑상선 유두암종 환자에 대한 PET-CT의 진단적 유용성에 대해 Choi 등'의 연구에서 다뤄진 바 있다. 본 증 례의 환자들도 방사성 요오드 스캔에서 이상 소견을 보이지 않았으나 PET-CT를 이용하여 후인두 림프절 전이를 진단할 수 있었다. PET-CT는 갑상선 유두암종 환자에서 간과하기 쉬운 후인두 림프절의 병변에 대해 직관적인 파악이 가능하 고, 전이성 병변과 혼동할 수 있는 염증성 병변이나 수술 후 발생한 생리적 변화와의 감별 진단에도 경부 CT보다 도움이 될 수 있다. 따라서 측경부 절제술의 병력이 있는 갑상선 유두 암종 환자들은 다른 두경부암 환자들처럼, 외래 추적 관찰 중 경부 초음파뿐만 아니라 후인두나 부인두의 림프절을 평 가하기 위해 조영 증강 경부 CT 혹은 필요시 PET-CT롤 통 한 평가가 필요할 것이다(Fig. 7).

본 증례 보고를 통해, 드물지만 갑상선 유두암종의 후인두 림프절 전이 가능성이 있는 경우, 즉 이전 경부 절제술의 병 력이 있으면서 $\mathrm{TG}-\mathrm{Ag}$ 수치의 상승이 있고 문진이나 신체 검 진 상에서 재발이나 전이 여부를 특정할 수 없을 때, CT나 MRI, PET-CT 등 영상 검사를 주기적으로 시행하면서 꾸준 한 외래 추적 관찰을 시행해야 한다는 것을 알 수 있고, 더 장기 추적 관찰을 해야겠지만 경부 접근법이나 로봇, 내시경 등을 이용한 수술이 아닌 보다 간단한 경구강 접근법으로도 잔여 병변 없이 절제가 가능하다는 것을 알 수 있다. 이는 드 물지만 갑상선 유두암종도 후인두 림프절로 전이할 수 있으 며, 단일 림프절로의 전이일 경우 수술적 치료가 가장 효과 적이기 때문에 놓치지 않고 진단해야 함을 시사한다.

\section{ORCID}

Jeong Soo Woo https://orcid.org/0000-0001-8075-0976

Jae Gu Cho https://orcid.org/0000-0003-0874-2271

\section{REFERENCES}

1) Otsuki N, Nishikawa T, Iwae S, Saito M, Mohri M, Nibu K. Retropharyngeal node metastasis from papillary thyroid carcinoma. Head Neck 2007;29(5):508-11.

2) Shellenberger T, Fornage B, Ginsberg L, Clayman GL. Transoral resection of thyroid cancer metastasis to lateral retropharyngeal nodes. Head Neck 2007;29(3):258-66.

3) Desuter G, Lonneux M, Plouin-Gaudon I, Jamar F, Coche E, Weynand B, et al. Parapharyngeal metastases from thyroid cancer. Eur J Surg Oncol 2004;30(1):80-4.

4) Togashi T, Sugitani I, Toda K, Kawabata K, Takahashi S. Surgical management of retropharyngeal nodes metastases from papillary thyroid carcinoma. World J Surg 2014;38(11):2831-7.

5) Lee JK, Lim SC. A case of parapharyngeal metastasis from papillary thyroid carcinoma. Korean J Otorhinolaryngol-Head Neck Surg 2005;48(6):807-9.

6) Park YM, Hong HJ, Yang WS, Choi EC. Retropharyngeal lymph node metastasis of thyroid papillary carcinoma. Korean J Otorhinolaryngol- 
Head Neck Surg 2009;52(1):88-92.

7) Chu HR, Bae WJ, Lee DJ, Koh ES, Rho YS. Retropharyngeal lymph node metastasis from thyroid carcinoma. J Korean Thyroid Assoc 2008;1(1):66-70.

8) Byeon HK, Duvvuri U, Kim WS, Park YM, Hong HJ, Koh YW, et al. Transoral robotic retropharyngeal lymph node dissection with or without lateral oropharyngectomy. J Craniofac Surg 2013;24(4): 1156-61.

9) Choi SJ, Jung KP, Lee SS, Park YS, Lee SM, Bae SK. Clinical usefulness of F-18 FDG PET/CT in papillary thyroid cancer with negative radioiodine scan and elevated thyroglobulin level or positive anti-thyroglobulin antibody. Nucl Med Mol Imaging 2016;50(2):130-6. 